\title{
SOSIALISASI DAN EDUKASI LITERASI KEUANGAN UNTUK WARGA ‘AISYIYAH KABUPATEN SUKOHARJO GUNA MENGURANGI PERILAKU KONSUMTIF PADA REMAJA DAN ANAK-ANAK
}

\author{
Dhany Efita Sari \\ Universitas Muhammadiyah Surakarta \\ email:des576@ums.ac.id
}

\begin{abstract}
People who are financially literate are people who have the attitudes, skills and knowledge to manage one's finances to meet financial goals that help achieve life goals. In fact, the majority of the citizens of 'Aisyiyah in Sukoharjo Regency have children who are extravagant or consumptive, like to follow trends, and are less able to prioritize their needs than their desires so that they cannot understand and apply financial literacy in life daily. Based on the conditions experienced by residents of Aisyiyah, Sukoharjo Regency, there is a need for financial education and outreach for adults to be able to be applied to their children. The education and socialization program provided is expected to reduce consumptive behavior in children and provide benefits to the residents of the community 'Aisyiyah Sukoharjo Regency to develop knowledge and understanding of financial literacy education and the ability to manage finances well.
\end{abstract}

Keywords: education; financial literacy; consumptive behaviour; children

\begin{abstract}
ABSTRAK
Orang yang melek finansial atau melek keuangan adalah orang yang memiliki sikap, keterampilan dan pengetahuan untuk mengelola keuangan seseorang guna memenuhi tujuan keuangan yang membantu dalam mencapai tujuan hidup. Faktanya, mayoritas warga masyarakat 'Aisyiyah Kabupaten Sukoharjo memiliki anak-anak dengan sifat hidup yang boros atau konsumtif, hobi mengikuti trend, dan kurang dapat memprioritaskan kebutuhannya daripada keinginannya sehingga dapat dikatakan anak-anak tersebut belum memahami dan menerapkan literasi keuangan atau melek keuangan dalam kehidupan sehari-hari. Berdasarkan kondisi yang dialami oleh warga 'Aisyiyah Kabupaten Sukoharjo tersebut, perlu adanya edukasi dan sosialisasi keuangan untuk orang dewasa yang nantinya bertujuan untuk dapat diterapkan kepada anak-anaknya. Program edukasi dan sosialisasi yang diberikan, diharapkan dapat mengurangi perilaku konsumtif pada anak dan memberikan manfaat kepada ibu-ibu warga 'Aisyiyah Kabupaten Sukoharjo untuk menumbuhkembangkan pengetahuan dan pemahaman mengenai edukasi literasi keuangan serta kemampuan dalam mengelola keuangan dengan baik.
\end{abstract}

Kata Kunci: pendidikan; literasi keuangan; perilaku konsumtif; anak-anak 


\section{PENDAHULUAN}

\section{Latar Belakang}

Perlambatan pertumbuhan ekonomi global memberikan dampak pada perekonomian di Indonesia. Pertumbuhan perekonomian di Indonesia saat ini mengalami kondisi naik turun yang tidak stabil. Terkait dengan hal ini, dapat dikatakan bahwa perekonomian di Indonesia sedang berada dalam tahap konsolidasi pada sektor rumah tangga dan perbankan. Faktanya, meski investasi membaik namun dalam sektor konsumsi mengalami perlambatan, dengan ini Bank Indonesia memprediksi perekonomian Indonesia berada pada kisaran $5 \%$ s.d. $5,4 \%$ pada tahun ini (Sugianto, 2019). Maka dari itu, Indonesia harus bekerja keras untuk dapat bersaing untuk menghadapi perekonomian global.

Perekonomian global menuntut masyarakat untuk memiliki tingkat literasi keuangan yang memadai sehingga masyarakat mampu menghadapi persaingan global saat ini. Berdasarkan realita di masyarakat, melek keuangan sangat dibutuhkan saat ini. Dampak yang akan didapatkan begitu besar baik dalam perkembangan perekonomian dan keuangan dalam sektor rumah tangga. Namun tingkat pengetahuan dan pemahaman masyarakat mengenai pentingnya keuangan masih rendah. Upaya meningkatkan pemahaman mengenai pentingannya keuangan perlu dilakukan dengan adanya edukasi literasi keuangan bagi sektor rumah tangga. Peningkatan pemahaman dapat dilakukan dengan sosialisasi dan pelatihan tentang literasi keuangan untuk sektor rumah tangga.

Seperti yang dijelaskan oleh Kempson dan Atkinson (2009) dan Lusardi (2008) bahwa orang yang melek finansial atau melek keuangan adalah orang yang memiliki sikap, keterampilan dan pengetahuan untuk mengelola keuangan seseorang guna memenuhi tujuan keuangan yang membantu dalam mencapai tujuan hidup (Durband \& Briit, 2012). Senada dengan hal tersebut, Johnson dan Sherraden (2007) mengemukakan sebuah konsep alternatif bahwa individu perlu mengembangkan pengetahuan dan keterampilan keuangan tetapi juga memperoleh akses terhadap kebijakan, instrumen dan layanan keuangan secara khusus. Johnson dan Serraden menekankan pentingnya "pengalaman keuangan" dalam konsep melek keuangan sesuai dengan yang dijelaskan oleh (Forte, et al., 2014).

Menurut hasil survai yang dilakukan (Otoritas Jasa Keuangan, 2013) tingkat indeks literasi keuangan masyarakat Indonesia sebesar 21,84\%, sedangkan survai (Otoritas Jasa Keuangan, 2016) menunjukkan tingkat indeks literasi keuangan masyarakat Indonesia sebesar 29,66\%. Tingkat literasi ini masih rendah jika dibandingkan dengan negara-negara di Asia Tenggara lainnya. Data tersebut menunjukkan bahwa tingkat kenaikan literasi keuangan tidak menunjukkan perubahan yang signifikan. Menurut OJK dalam redaksi yang dipaparkan oleh Murdaningsih, tingkat literasi keuangan perempuan hanya sebesar $25 \%$ yang berarti lebih rendah 
daripada laki-laki sebesar 33\% (Murdaningsih, D., \& Septyaningsih, I, 2017). Dalam rangka meningkatkan tingkat literasi keuangan masyarakat Indonesia, pihak OJK meluncurkan program Cetak Biru yang bertujuan untuk memberikan pengetahuan kepada masyarakat yang not literated (tidak melek) atau less literated (kurang melek) agar dapat lebih memahami literasi keuangan yang sasarannya antara lain sekolah, mahasiswa, ibu rumah tangga hingga pengusaha ekonomi lemah (Zuraya, 2013).

Zuraya menambahkan dalam redaksinya, OJK memaparkan bahwa pengetahuan mengenai literasi keuangan tidak hanya ditujukan untuk orangorang dewasa seperti ibu rumah tangga saja namun seharusnya anak-anak mereka juga harus diberi pengetahuan mengenai literasi keuangan yang ditanamkan sejak usia dini (2013). Pendidikan literasi keuangan sangat dibutuhkan dalam mendidik anak sejak pra sekolah dan sekolah dasar. Adanya pendidikan literasi keuangan kepada anak sejak dini akan dapat melatih anak untuk dapat mengelola keuangan dengan baik di masa yang akan datang, dengan begitu anak dapat mengontrol apa yang yang menjadi keperluan mereka agar tidak menjadikan mereka boros. Apabila generasi muda sudah terbiasa dengan mengelola keuangan sejak dini maka akan berdampak positif untuk anak yang bermanfaat untuk jangka panjang.

Pendidikan literasi keuangan tidak lepas dari pengaruh orang tua. Anak dengan orang tua yang berpenghasilan menengah kebawah akan memberikan uang kepada anak secukupnya atau sesuai dengan kemampuan orang tua, dengan begitu anak harus dapat mengelola keuangan dengan baik. Di lain pihak, anak yang memiliki orang tua dengan penghasilan menengah keatas akan cenderung memberikan uang lebih kepada anaknya namun hal ini berdampak buruk untuk masa depan keluarga dan anak itu sendiri dalam hal pengelolaan keuangan. Hal ini akan menimbulkan perilaku anak yang terbiasa hidup boros atau konsumtif. Cara yang dilakukan orang tua seperti itu dirasa salah karena dengan membiasakan memberikan uang berlebihan kepada anak akan membuat anak merasa acuh dan seenaknya sendiri dengan uang yang dimiliki dan orang tua secara berangsur-angsur tidak akan menerima kesejahteraan dihari tuanya. Orang tua tidak akan menerima hasil jerih payahnya di kemudian hari, yang disebabkan oleh ketidakmampuan orang tua dalam mengelola keuangan dengan baik dan secara otomatis anak akan meniru gaya hidup orang tuanya. Maka dari itu agar tidak terjadi hal yang tidak diinginkan, orang tua harus dapat melatih anak dalam mengelola keuangan dengan cara membiasakan hidup dengan menyisihkan uang atau menabung, serta mengontrol anak untuk tidak membelanjakan uang secara boros atau konsumtif (Ardiana, 2016).

Masyarakat 'Aisyiyah Kabupaten Sukoharjo merupakan suatu organisasi atau perkumpulan gerakan wanita Islam yang memberikan berbagai amal usaha seluas-luasnya dan bertugas untuk mendayagunakan kaum putri dan kaum ibu dalam rangka mendakwahkan agama Islam di 
Kabupaten Sukoharjo pada khususnya. Selain mendakwahkan agama islam kepada masyarakat, 'Aisyiyah Kabupaten Sukoharjo memberikan amal usaha kepada masyarakat sekitar antara lain dibidang pendidikan, kesehatan, kesejahteraan sosial, ekonomi dan pemberdayaan masyarakat. Seiring berjalannya waktu 'Aisyiyah Kabupaten Sukoharjo selalu meningkatkan kemampuan dalam mendayagunakan perempuan agar dapat berperan aktif di masyarakat serta meningkatkan harkat perempuan Sukoharjo pada khususnya, dalam publikasi website official dengan alamat http://www.muhammadiyah.or.id/.

Berdasarkan wawancara kepada masyarakat 'Aisyiyah Kabupaten Sukoharjo, ketika membahas mengenai ekonomi baik dalam hal pemasukan, pengeluaran serta pengelolaan uang justru selalu berkaitan dengan anak-anak mereka. Ketika ditanya lebih lanjut, banyak masyarakat yang memiliki anak-anak dengan sifat hidup yang boros atau konsumtif. Mayoritas anak terbiasa mengikuti perkembangan zaman sekarang yang sering dikatakan dengan trend. Trend pada saat ini tidak bisa dipungkiri baik dari anak-anak, remaja maupun orang tua. Adanya trend di kalangan anakanak dan remaja saat ini berdampak buruk bagi masa depan mereka dikarenakan tidak bisa menghargai uang dengan baik.

Perilaku seorang anak dan remaja yang konsumtif berbanding terbalik dengan seorang anak yang dapat menggunakan uang dengan bijak. Pada sebagian anak dan remaja, mereka cenderung berkeinginan untuk menabung jika sudah beranjak dewasa, dan pada kenyataannya kebutuhan yang terjadi semakin tinggi dan naik sedangkan inflasi juga akan naik seiring berjalannya waktu. Namun ada sebagian remaja yang terlatih untuk menggunakan uang secara bijak dengan cara menabung dari kecil atau pra sekolah dan sudah berpikir untuk melakukan investasi untuk masa depannya. Maka dari itu anak-anak tersebut perlu diberikan adanya edukasi mengenai literasi keuangan.

\section{Tujuan}

Edukasi literasi keuangan merupakan bagian penting dari sebuah pendidikan. Pendidikan keuangan menjadi kunci bagi setiap orang dalam pengambilan keputusan yang berhubungan dengan keuangan. Kemampuan memahami produk keuangan yang ditawarkan terdapat dalam berbagai bentuk atau perilaku keuangan akan mencerminkan melek keuangan dari masing-masing orang. Rendahnya tingkat melek keuangan adalah masalah di seluruh dunia. (Mihalcova, et al., 2014). Berdasarkan permasalahanpermasalahan yang telah dijelaskan sebelumnya, maka peneliti tertarik untuk melakukan pengabdian kepada masyarakat dengan judul "Sosialisasi dan Edukasi Literasi Keuangan untuk Warga Aisyiyah Kabupaten Sukoharjo Guna Mengurangi Perilaku Konsumtif Pada Remaja dan Anak-anak". 


\section{Kajian Pustaka}

Kempson dan Atkinson (2009) dan Lusardi (2008) menjelaskan bahwa orang yang melek finansial atau melek keuangan adalah orang yang memiliki sikap, keterampilan dan pengetahuan untuk mengelola keuangan seseorang guna memenuhi tujuan keuangan yang membantu dalam mencapai tujuan hidup (Durband \& Briit, 2012). Senada dengan hal tersebut, Johnson dan Sherraden (2007) mengemukakan sebuah konsep alternatif bahwa individu perlu mengembangkan pengetahuan dan keterampilan keuangan tetapi juga memperoleh akses terhadap kebijakan, instrumen dan layanan keuangan secara khusus. Johnson dan Serraden menekankan pentingnya "pengalaman keuangan" dalam konsep melek keuangan sesuai dengan yang dijelaskan oleh (Forte, Taylor \& Tisdell, 2014).

Zuraya menambahkan dalam redaksinya, OJK memaparkan bahwa pengetahuan mengenai literasi keuangan tidak hanya ditujukan untuk orangorang dewasa seperti ibu rumah tangga saja namun seharusnya anak-anak mereka juga harus diberi pengetahuan mengenai literasi keuangan yang ditanamkan sejak usia dini (2013). Pendidikan literasi keuangan sangat dibutuhkan dalam mendidik anak sejak pra sekolah dan sekolah dasar. Adanya pendidikan literasi keuangan kepada anak sejak dini akan dapat melatih anak untuk dapat mengelola keuangan dengan baik di masa yang akan datang, dengan begitu anak dapat mengontrol apa yang yang menjadi keperluan mereka agar tidak menjadikan mereka boros. Apabila generasi muda sudah terbiasa dengan mengelola keuangan sejak dini maka akan berdampak positif untuk anak yang bermanfaat untuk jangka panjang.

\section{METODE PELAKSANAAN}

Tujuan akhir pendidikan keuangan adalah memberikan pengarahan kepada anak dan remaja sehingga mereka dapat membuat keputusan yang tepat dan bertanggung jawab atas keputusan mereka berdasarkan situasi dan pengelolaan keuangan mereka saat ini yang menunjukkan pengelolaan keuangan yang sedemikian rupa agar tidak menjadi beban bagi keluarga atau masyarakat sekitar. Terdapat beberapa metode dalam memberikan pendidikan keuangan (Mihalcova, Csikosva, \& Antosone, 2014), hal tersebut antara lain adalah sebagai berikut:

1. Pendidikan keuangan dalam kurikulum sekolah formal (taman kanakkanak, sekolah dasar, sekolah menengah, institusi pendidikan tinggi).

2. Kursus pelatihan dan seminar pendidikan keuangan untuk orang dewasa.

3. Pendidikan keuangan yang diberikan oleh lembaga nasional atau regional serta lembaga non-pemerintah dan sektor jasa keuangan.

Berdasarkan kondisi yang dialami oleh warga 'Aisyiyah Kabupaten Sukoharjo, perlu adanya sosialisasi dan edukasi tentang pentingnya menerapkan literasi keuangan. Program sosialisasi dan edukasi yang diberikan, diharapkan dapat memecahkan permasalahan mengenai keuangan yang dapat memberikan manfaat kepada ibu-ibu 'Aisyiyah Kabupaten 
Sukoharjo untuk menumbuhkembangkan pengetahuan dan pemahaman mengenai edukasi literasi keuangan serta kemampuan dalam mengelola keuangan dengan baik.

Metode pelaksanaan dalam program ini dilakukan dengan memberikan kursus pelatihan pendidikan keuangan bagi orang dewasa dengan tujuan untuk dapat ditularkan kepada ank-anaknya (Mihalčová, Csikósová, \& Antošová, 2014). Data diambil dengan menggunakan kuesioner untuk mengukur tingkat literasi keuangan (perilaku menabung) pada anak. Responden sejumlah 25 anak yang merupakan anak-anak dari ibu-ibu Warga 'Aisyiyah yang mengikuti sosialisi dan edukasi literasi keuangan. Data perilaku menabung anak dianalisis dengan menggunakan analisis kuantitatif secara deskriptif.

Terkait dengan hal tersebut, perlu adanya sosialisasi tentang cara untuk mengatur pengeluaran bagi ibu-ibu warga Aisiyah Kabupaten Sukoharjo yang akan berdampak pada berkurangnya perilaku konsumtif remaja dan anak-anak. Cara mengatur pengeluaran dapat dilakukan dengan menabung dan investasi. Bagi beberapa orang, sebagian sudah memiliki pemikiran untuk menyisihkan uangnya dengan menabung namun sebagian orang masih berpikiran tidak ingin menabung pada saat ini karena lebih mengutamakan kepentingan sekarang dibandingkan kepentingan di masa yang akan datang.

Menurut Child Development Accounts (CDA) dijelaskan bahwa memiliki tabungan di masa kanak-kanak merupakan dasar sebagai penghubung institusi perbankan dalam melakukan diversifikasi portofolio aset di masa remaja dan seterusnya. Anak-anak mungkin memiliki tabungan terbatas untuk diinvestasikan pada awalnya, namun mereka adalah pelaku keuangan yang mungkin semakin menginvestasikan uang ke berbagai jenis produk tabungan dari waktu ke waktu. Memiliki tabungan di masa kecil dikaitkan dengan dua kali kemungkinan untuk memiliki rekening tabungan, dua kali kemungkinan untuk memiliki kartu kredit dan empat kali kemungkinan memiliki saham di usia remaja, dibandingkan dengan tidak memiliki rekening tabungan di masa kecil. (Friedline, et al., 2013)

Berdasarkan hal tersebut, sosialiasi dan edukasi yang akan dilaksanakan dapat memberikan pemahaman kepada ibu-ibu 'Aisyiyah Kabupaten Sukoharjo agar lebih memiliki pemikiran ke depan bahwa orang tua yang mengajarkan anaknya untuk membiasakan menabung akan memberikan manfaat kesejahteraan yang lebih baik untuk anak dibandingkan dengan anak yang tidak memiliki rekening tabungan di masa kecilnya. Pada awal proses menabung di masa kanak-kanak, menjadi suatu kewajaran jika anak belum dapat melakukan investasi. Namun seiring berjalannya waktu, melalui kebiasaan menabung, anak-anak akan termotivasi untuk mulai menginvestasikan uang guna peningkatan kesejahteraan di masa yang akan datang.

Peluang investasi saat ini telah berkembang melampaui batas nasional yang memungkinkan individu untuk berinvestasi dalam berbagai aset. Pergeseran dari manfaat ke iuran terjadi secara bertahap dalam keterlibatan 
pengusaha untuk memberikan jaminan pensiun kepada pekerja, yang berarti bahwa individu harus memutuskan berapa banyak yang harus dihemat dan bagaimana mengalokasikan kekayaan pensiun mereka. Keputusan untuk menghemat serta pengambilan keputusan yang bijak dan tepat waktu dapat menjadi kunci keamanan keuangan. (Scheresberg \& Carlo, 2013)

Adanya kegiatan menabung yang diajarkan oleh ibu-ibu 'Aisyiyah Kabupaten Sukoharjo kepada anak mereka sejak kecil, dapat berangsurangsur untuk melakukan investasi dengan tabungan yang dimilikinya. Jika ibuibu 'Aisyiyah Kabupaten Sukoharjo menginginkan kesejahteraan dalam jangka pendek bagi anak, bisa dilakukan dengan membiasakan anak untuk menabung. Namun jika ibu-ibu 'Aisyiyah Kabupaten Sukoharjo menginginkan kesejahteraan anak untuk jangka panjang, maka ibu-ibu 'Aisyiyah Kabupaten Sukoharjo harus dapat mendorong minat anak-anak sejak kecil untuk rajin menabung yang akhirnya akan digunakan untuk investasi demi masa depan anak.

Instrumen yang digunakan untuk mengukur perilaku menabung dalam penelitian ini adalah angket. Angket digunakan untuk mengukur indikatorindikator perilaku menabung pada anak, yaitu keterlibatan anak dalam menabung, sikap terhadap tabungan, tujuan tabungan, perilaku keuangan, sikap orang tua dan rekan yang dirasakan terhadap penghematan uang, niat dan kemauan orang tua dan rekan terhadap penghematan uang (Zaichkowsky, 1994; Belch, 1982; Te'eni-Harari et al., 2009, 2013, 2016; Ajzen, 1988; Gudmunson \& Danes, 2011). Lebih lanjut, pengukuran perilaku menabung pada anak dapat dijelaskan sebagai berikut,

Tabel 1.

Pengukuran Perilaku Menabung pada Anak

\begin{tabular}{|c|c|c|c|}
\hline No. & Indikator & Pertanyaan & Pilihan Jawaban \\
\hline 1. & $\begin{array}{l}\text { Keterlibatan anak } \\
\text { dalam menabung }\end{array}$ & $\begin{array}{l}\text { Seberapa sering anda } \\
\text { menabung? }\end{array}$ & $\begin{array}{l}\text { a. Sangat sering } \\
\text { b. Sering } \\
\text { c. Jarang } \\
\text { d. Sangat jarang } \\
\text { e. Tidak pernah }\end{array}$ \\
\hline \multirow[t]{3}{*}{2.} & \multirow[t]{3}{*}{$\begin{array}{ll}\text { Sikap } & \text { terhadap } \\
\text { tabungan } & \end{array}$} & $\begin{array}{l}\text { Apakah menabung itu } \\
\text { baik? }\end{array}$ & $\begin{array}{l}\text { a. Sangat baik } \\
\text { b. Baik } \\
\text { c. Biasa saja } \\
\text { d. Buruk } \\
\text { e. Sangat buruk }\end{array}$ \\
\hline & & $\begin{array}{l}\text { Apakah pintar/bodoh anak } \\
\text { yang menabung? }\end{array}$ & $\begin{array}{l}\text { a. Sangat pintar } \\
\text { b. Pintar } \\
\text { c. Biasa saja } \\
\text { d. Bodoh } \\
\text { e. Sangat bodoh }\end{array}$ \\
\hline & & $\begin{array}{l}\text { Haruskah seseorang } \\
\text { menabung? }\end{array}$ & $\begin{array}{l}\text { a. Sangat harus } \\
\text { b. Harus } \\
\text { c. Ragu-ragu } \\
\text { d. Sangat tidak harus }\end{array}$ \\
\hline
\end{tabular}




\begin{tabular}{|c|c|c|c|}
\hline & & & e. Tidak perlu \\
\hline \multirow[t]{2}{*}{3.} & \multirow[t]{2}{*}{ Tujuan tabungan } & $\begin{array}{l}\text { Jika Anda diberi uang untuk } \\
\text { acara ulang tahun Anda, } \\
\text { maukah anda berhemat } \\
\text { dan menabungnya? }\end{array}$ & $\begin{array}{l}\text { a. Sangat mau } \\
\text { b. Mau } \\
\text { c. Ragu-ragu } \\
\text { d. Tidak mau } \\
\text { e. Sangat tidak mau }\end{array}$ \\
\hline & & $\begin{array}{l}\text { Jika Anda diberi uang, } \\
\text { apakah itu penting bagi } \\
\text { Anda? }\end{array}$ & $\begin{array}{l}\text { a. Sangat penting } \\
\text { b. Penting } \\
\text { c. Ragu-ragu } \\
\text { d. Tidak penting } \\
\text { e. Sangat tidak penting }\end{array}$ \\
\hline \multirow[t]{2}{*}{4.} & \multirow[t]{2}{*}{ Perilaku keuangan } & $\begin{array}{l}\text { Apakah Anda menyimpan } \\
\text { uang di dalam kotak } \\
\text { tabungan? }\end{array}$ & $\begin{array}{l}\text { a. Selalu } \\
\text { b. Sering } \\
\text { c. Jarang } \\
\text { d. Pernah } \\
\text { e. Tidak pernah } \\
\end{array}$ \\
\hline & & $\begin{array}{l}\text { Tahukah Anda berapa } \\
\text { banyak uang yang Anda } \\
\text { miliki sekarang? }\end{array}$ & $\begin{array}{l}\text { a. Tahu persis } \\
\text { b. Kurang tahu persis } \\
\text { c. Ragu-ragu } \\
\text { d. Tidak tahu } \\
\text { e. Sama sekali tidak tahu }\end{array}$ \\
\hline 5. & $\begin{array}{l}\text { Sikap orang tua dan } \\
\text { rekan (teman) terhadap } \\
\text { penghematan uang }\end{array}$ & $\begin{array}{l}\text { Apa tanggapan rekan Anda } \\
\text { dan orang tua Anda tentang } \\
\text { menabung }\end{array}$ & $\begin{array}{l}\text { a. Sangat bagus } \\
\text { b. Bagus } \\
\text { c. Biasa saja } \\
\text { d. Tidak bagus } \\
\text { e. Sangat tidak bagus }\end{array}$ \\
\hline 6. & $\begin{array}{l}\text { Niat dan kemauan } \\
\text { orang tua dan rekan } \\
\text { terhadap penghematan } \\
\text { uang }\end{array}$ & $\begin{array}{l}\text { Seberapa penting rekan } \\
\text { Anda dan } \\
\text { sikap orang tua Anda untuk } \\
\text { menabung adalah untuk } \\
\text { Anda? }\end{array}$ & $\begin{array}{l}\text { a. Sangat penting } \\
\text { b. Penting } \\
\text { c. Ragu-ragu } \\
\text { d. Tidak penting } \\
\text { e. Sangat tidak penting }\end{array}$ \\
\hline
\end{tabular}

Adapun program-program yang akan dilaksanakan dalam mendukung rencana pengabdian kepada masyarakat terkait dengan penerapan literasi keuangan pada ibu-ibu warga masyarakat 'Aisyiyah Kabupaten Sukoharjo disajikan pada tabel 1 .

Tabel 2.

Rencana kegiatan yang akan dilaksanakan dalam mendukung program "Sosialisasi dan Edukasi Literasi Keuangan pada lbu-ibu Warga Masyarakat Aisyiyah Kabupaten Sukoharjo"

\begin{tabular}{clll}
\hline No & \multicolumn{1}{c}{ Program } & \multicolumn{2}{c}{ Tahun ke- } \\
\cline { 3 - 4 } 1 & $\begin{array}{l}\text { Pendataan kondisi ekonomi orang tua beserta anak (warga } \\
\text { masyarakat 'Aisyiyah Kab. Sukoharjo) sebelum kegiatan Pemitra }\end{array}$ & \\
\hline & $\begin{array}{l}\text { Sosialisasi dan edukasi literasi keuangan untuk ibu-ibu warga } \\
\text { masyarakat 'Aisyiyah Kabupaten Sukoharjo sebanyak 1 kali } \\
\text { selama program dalam 1 tahun }\end{array}$ & \\
\hline
\end{tabular}




\begin{tabular}{lll}
\hline No & \multicolumn{1}{c}{ Program } & \multicolumn{2}{c}{ Tahun ke- } \\
\cline { 3 - 3 } 3 & $\begin{array}{l}\text { Sosialisasi dan edukasi literasi keuangan untuk anak-anak dan } \\
\text { remaja warga masyarakat 'Aisyiyah Sukoharjo }\end{array}$ & \\
\hline 4 & Evaluasi dan tindak lanjut program secara keseluruhan \\
\hline
\end{tabular}

Selanjutnya, luaran yang diharapkan melalui program pengabdian ini dapat dijelaskan sebagai berikut:

1. Ibu-ibu warga 'Aisyiyah Sukoharjo dapat menerapkan literasi keuangan dalam kehidupan sehari-hari. Adanya pemahaman dan penerapan literasi keuangan yang baik akan bermanfaat untuk jangka panjang baik bagi orang tua maupun anak-anak dan remaja.

2. Ibu-ibu warga 'Aisyiyah Sukoharjo mulai menerapkan kebiasaan hidup hemat dengan mengurangi pengeluaran kebutuhan yang tidak diperlukan.

3. Ibu-ibu warga 'Aisyiyah Sukoharjo yang telah mendapat sosialisasi dan pelatihan tentang literasi keuangan dapat mulai membiasakan hal yang serupa pada anak-anaknya yaitu dengan membiasakan anaknya menabung guna menyongsongn masa depan yang lebih baik.

4. Anak-anak warga 'Aisyiyah Sukoharjo terbiasa menabung baik di rumah maupun di sekolah dan perilaku konsumtif anak dapat berkurang.

\section{HASIL DAN PEMBAHASAN}

Pelaksanaan kegiatan sosialisasi mengenai edukasi literasi keuangan kepada ibu-ibu 'Aisyiyah Kabupaten Sukoharjo telah dilaksanakan pada hari Sabtu, 7 Juli 2018 yang bertempat di Pimpinan Daerah 'Aisyiyah (PDA) Kabupaten Sukoharjo. Peserta sosialisasi dan edukasi literasi keuangan sebanyak 25 orang peserta yang merupakan pengurus dan kader 'Aisyiyah Kabupaten Sukoharjo. Sosialisasi dan edukasi membahas tentang apa makna literasi keuangan, bagaimana menerapkan literasi keuangan di keluarga, dan bagaimana mendidik anak serta remaja di dalam keluarga untuk gemar menabung dan melek secara finansial. Keberlanjutan dari program sosialisasi yang utamanya membahas tentang kegiatan menabung guna mengurangi kebiasaan hidup boros atau konsumtif pada anak-anak warga 'Aisyiyah Kabupaten Sukoharjo, telah dilaksanakan. Selanjutnya, kegiatan monitoring akan dilaksanakan pada tahun kedua agar dapat mengamati kemajuan atau perubahan yang dirasakan oleh ibu-ibu 'Aisyiyah Kabupaten Sukoharjo ke arah yang lebih baik dan sejahtera. Selain menabung, program kami di tahun kedua yakni membidik ibu-ibu 'Aisyiyah Kabupaten Sukoharjo agar dapat mendorong minat anak mereka untuk berinvestasi melalui sosialisasi pentingnya tabungan dan investasi untuk masa depan anak yang akan dilaksanakan pada tahun kedua. 
Berdasarkan hasil diskusi dengan pengurus dan kader 'Aisyiyah Kabupaten Sukoharjo, dapat diambil kesimpulan bahwa sosialisasi dan edukasi literasi keuangan ini bertujuan untuk memberikan pemahaman mengenai pengelolaan keuangan agar dapat mendayagunakan uang untuk dijadikan tabungan maupun investasi (memulai usaha). Adanya pemikiran oleh ibu-ibu 'Aisyiyah Kabupaten Sukoharjo mengenai keberlanjutan uang untuk usaha akan berdampak pada anak agar dapat membiasakan diri untuk tidak mengikuti trend namun lebih tertarik untuk menabung dan berinvestasi agar dapat mendirikan suatu usaha baik sektor jasa, dagang, usaha rumahan maupun usaha lainnya sedini mungkin. Melalui pengetahuan yang cukup tentang literasi keuangan yang telah disosialisasikan pada ibu-ibu 'Aisyiyah Kabupaten Sukoharjo, diharapkan dapat disalurkan kepada anak agar anak memiliki kemampuan dalam menciptakan suatu usaha yang berguna untuk mengubah gaya hidup yang konsumtif menjadi lebih bijaksana dalam mengelola keuangannya.

Pelaksanaan kegiatan sosialisasi mengenai edukasi literasi keuangan kepada ibu-ibu 'Aisyiyah Kabupaten Sukoharjo telah dilaksanakan pada hari Sabtu, 7 Juli 2018 yang bertempat di Pimpina Daerah 'Aisyiyah (PDA) Kabupaten Sukoharjo. Peserta sosialisasi dan edukasi literasi keuangan sebanyak 25 orang peserta yang merupakan pengurus dan kader 'Aisyiyah Kabupaten Sukoharjo. Sosialisasi dan edukasi membahas tentang apa makna literasi keuangan, bagaimana menerapkan literasi keuangan di keluarga, dan bagaimana mendidik anak serta remaja di dalam keluarga untuk gemar menabung dan melek secara finansial. Keberlanjutan dari program sosialisasi yang utamanya membahas tentang kegiatan menabung guna mengurangi kebiasaan hidup boros atau konsumtif pada anak-anak warga 'Aisyiyah Kabupaten Sukoharjo, telah dilaksanakan. Selanjutnya, kegiatan monitoring akan dilaksanakan pada tahun kedua agar dapat mengamati kemajuan atau perubahan yang dirasakan oleh ibu-ibu 'Aisyiyah Kabupaten Sukoharjo ke arah yang lebih baik dan sejahtera. Selain menabung, program kami di tahun kedua yakni membidik ibu-ibu 'Aisyiyah Kabupaten Sukoharjo agar dapat mendorong minat anak mereka untuk berinvestasi melalui sosialisasi pentingnya tabungan dan investasi untuk masa depan anak yang akan dilaksanakan pada tahun kedua.

Berdasarkan hasil diskusi dengan pengurus dan kader 'Aisyiyah Kabupaten Sukoharjo, dapat diambil kesimpulan bahwa sosialisasi dan edukasi literasi keuangan ini bertujuan untuk memberikan pemahaman mengenai pengelolaan keuangan agar dapat mendayagunakan uang untuk dijadikan tabungan maupun investasi (memulai usaha). Adanya pemikiran oleh ibu-ibu 'Aisyiyah Kabupaten Sukoharjo mengenai keberlanjutan uang untuk usaha akan berdampak pada anak agar dapat membiasakan diri untuk tidak mengikuti trend namun lebih tertarik untuk menabung dan berinvestasi agar dapat mendirikan suatu usaha baik sektor jasa, dagang, usaha rumahan maupun usaha lainnya sedini mungkin. Melalui pengetahuan yang cukup tentang literasi 
keuangan yang telah disosialisasikan pada ibu-ibu 'Aisyiyah Kabupaten Sukoharjo, diharapkan dapat disalurkan kepada anak agar anak memiliki kemampuan dalam menciptakan suatu usaha yang berguna untuk mengubah gaya hidup yang konsumtif menjadi lebih bijaksana dalam mengelola keuangannya.

\section{KESIMPULAN}

Sosialisasi dan edukasi literasi keuangan yang dilakukan pada Ibu-ibu warga 'Aisyiyah Sukoharjo dapat diterapkan dalam kehidupan sehari-hari. Ibuibu mulai memahami pentingnya literasi keuangan dan menerapkan literasi keuangan dalam kehidupan sehari-hari. Selain itu, Ibu-ibu warga 'Aisyiyah Sukoharjo mulai menerapkan kebiasaan hidup hemat dengan mengurangi pengeluaran kebutuhan yang tidak diperlukan. Pada akhirnya, anak-anak warga 'Aisyiyah Sukoharjo terbiasa menabung baik di rumah maupun di sekolah sehingga perilaku konsumtif anak dapat berkurang.

\section{DAFTAR RUJUKAN}

Ajzen, I. (1988). From intentions to actions: attitudes, personality, \& behavior. Chicago: Dorsey Press.

Ardiana, M. (2016). Kontrol Diri, Pendidikan Pengelolaan Keuangan Keluarga, Pengetahuan Inklusi Keuangan Siswa Pengaruhnya Terhadap Perilaku Menabung Siswa SMK se-Kota Kediri. Jurnal Ekonomi Pendidikan dan Kewirausahaan Vol. 4. No. 1.

Belch, M.A., et al. (1982). Psychophysiological and Cognitive Responses to Sex in Advertising, in NA. Advances in Consumer Research. Volume 09, eds. Andrew Mitchell, Ann Abor, MI : Association for Consumer Research, Pages: 424-427

Durband, D.B., \& Britt, S.L. (2012). Student Financial Literacy: Campus-Based Program Development p127.

Forte, S.P., Taylor, E.W., Tisdell, E.J. (2014). Financial Literacy and Adult Education: New Direction for Adult and Continuing Education. number 141. New York: Wiley Online Library.

Friedline, T., Elliott, W., \& Chowa. (2013). Connections with Banking Institutions and Diverse asset Portfolios in Young Adulthood: Children as potential future investor. Children and Youth Service Review. 35, p994-1006.

Gudmunson, C.G, \& Danes, S.M. (2011). Family Financial Socialization: Theory and Critical Review. Journal of Family and Economic Issues. 32 (4). pp 644-667.

Mihalcova, B., Csikosva, A., \& Antosone, M. (2014). Financial Literacy-The Urgent Need Today. Social and Behavioral Sciences. Volume 109, p317321.

Murdaningsih, D., \& Septyaningsih, I. (Januari, 2017). Survei OJK: Pria Lebih Paham Industri Keuangan Dibanding Perempuan diakses melalui http://www.republika.co.id/berita/ekonomi/keuangan/17/01/24/oka7d736 
8-survei-ojk-pria-lebih-paham-industri-keuangan-dibanding-perempuan pada tanggal 23 November 2017.

Otoritas Jasa Keuangan (OJK). (2016). Survey National Literasi dan Inklusi Keuangan 2016-OJK diakses melalui website

http://www.ojk.go.id/id/berita-dan-kegiatan/siaran-

pers/Documents/Pages/Siaran-Pers-OJK-Indeks-Literasi-dan-Inklusi-

Keuangan-

Meningkat/17.01.23\%20Tayangan\%20\%20Presscon\%20\%20nett.compr essed.pdf pada tanggal 23 November 2017.

Scheresberg, D.B \& Carlo. (2013). Financial Literacy and Financial Behavior among Young Adults: Evidence and Implication. Advancing Education in Quantitative Literacy. Volume 6 (1552), Article 5.

Te'eni-Harari, T., et.al. (2009). The importance of product involvement for predicting advertising effectiveness among young people. International Journal of Advertising, 28(2), pp. 203-229.

Te'eni-Harari, T. (2013). Explaining the Relationship Between Media Exposure and Early Adolescents' Body Image Perceptions. Journal of Media Psychology, 25, pp. 129-141.

Te'eni-Harari, T. (2016). Financial Literacy Among Children: The Role of Involvement in Savings Money. Young Consumers. Volume 14 (2), pp 197-208.

Yolanda, F., \& Zuraya, N. (Desember, 2013). Tahun depan, OJK Bidik Ibu Rumah Tangga diakses melalui website http://www.republika.co.id/berita/ekonomi/keuangan/13/12/02/mx5rm3tahun-depan-ojk-bidik-ibu-rumah-tangga pada tanggal 23 November 2017.

Zaichkowsky, J.L. (1994). The Personal Involvement Inventory: Reduction, Revision, and Application to Advertising. Journal of Advertising. Volume 23 (4), pp 59-70.

Zuraya, N. (November, 2013). OJK Luncurkan Cetak Biru Literasi Keuangan Indonesia diakses melalui website http://www.republika.co.id/berita/ekonomi/keuangan/13/11/19/mwhvzeojk-luncurkan-cetak-biru-literasi-keuangan-indonesia pada tanggal 23 November 2017. 